\title{
Employee Engagement - Making Internal Customer Happier
}

\author{
I. Yabesh Abraham Durairaj, T. Thiruvenkadam, Mu. Subrahmanian
}

\begin{abstract}
This paper empirically analysed Employee Engagement in the NBFC's located in the Districts of Chennai, Kancheepuram and Thiruvallur of Tamilnadu, India, by considering the three dimensions such as, Vigor, Absorption and Dedication. The respondents for the study were 321 employees employed with different NBFC's located in the Districts of Chennai, Kancheepuram and Thiruvallur of Tamilnadu, India. The result of the study showed that there are more respondents with High level of Employee Engagement and in the Dimensions of Employee Engagement, more respondents have Low level of Vigor; and Moderate level of Dedication and Absorption.
\end{abstract}

\section{Index Terms: Employee Engagement, Gender, and NBFC's.}

\section{INTRODUCTION}

The notion of employee engagement has received substantial attention in the bygone decade as organizational front-runners seek ways to capture the full potential of their employees. Technology has provided a momentous portion to enhancements in employee efficiency in current years, taking some of the human component out of job, but individuals are still the chief means in promoting organizational performance. While enhanced technology can be procured as scientific improvements develop year after year, refining the employee using the technology and the environment in which they coexist is not as upfront.

Understanding how to tie together individual competences that not only end in a optimistic return to organizations, but also captures the desire, imagination, and involvement of internal customers has in part powered much of the study related to Employee Engagement. Some of the queries driving the study focus on knowing what circumstances need to be present in a work setting that enables engagement, the role managers, coworkers, have in building engagement, and whether monetary inducements enables augmented engagement. Abundant consideration has come from information consulting firms have piled up, which advises less than one-third of workforces are actually engaged in their job (Towers Perrin, 2003, 2007, Wagner \& Harter, 2006).

\section{REVIEW OF LITERATURE}

Employee engagement is an vigorous, optimistic job related state that is featured by vigor, dedication, and absorption (Schaufeli et al., 2006). Employee engagement is

Revised Manuscript Received on July 05, 2019.

I. Yabesh Abraham Durairaj, Department of Management Studies, Panimalar Engineering College, Chennai.

Dr. T. Thiruvenkadam, SSN School of Management, Chennai.

Dr. Mu. Subrahmanian, Faculty of Business Studies, Arab Open University, Muscat, Sultanate of Oman. an autonomous, tireless and persistent motivational mental state that complements the behavioural investment of individual vigour (Schaufeli and Bakker, 2010). As a motivational mental state, employee engagement is a reaction to one's job. Engagement is explicitly related to the employees', 'presenting and absenting themselves in the course of job performances'. In other verses, it is almost association of 'self' in the job (Berkel et al., 2011).

Diverse meanings have been suggested for employee engagement in the collected works. Some of them are here. Kahn (1990) created one of the most recognizable explanations of engagement: "the harnessing of organizational members' selves to their work role". Work engagement is well-defined as "a positive, fulfilling, work-related state of mind characterized by vigor, dedication, and absorption" and can encourage employee wellbeing (Inoue et al., 2013). Work engagement is a state of passionate and whole association in job (Rich et al., 2010; Cooper-Thomas et al., 2014). Work engagement can be well-defined as 'a positive, fulfilling, affective-motivational state of work related well-being that is characterized by vigor, dedication, and absorption' (Kanste, 2011). Work engagement is a transitory, optimistic, fulfilling and job related state of mind that is characterized by vigor, dedication and absorption and varies within peoples over a short span of time (Breevaart et al., 2013; Breevaart et al., 2014).

Employee engagement is composed of three dimensions: vigor, dedication and absorption. Vigor refers to energy, mental resilience, willpower and investing constant effort in work (Rayton and Yalabik, 2014). Vigor is a feature of work engagement that suggests high levels of energy and mental flexibility while operational. There is also a single-minded outlay in the real job, along with elevated levels of determination even when faced with problems.

This feature can be examined based on Atkinson's motivational theory. Motivation is power of doing job or confrontation against that. So, power and confrontation are explained as a part of job engagement and their notion is persistent with prevalent explanation of motivation (Latham and Pinder, 2005). The second element, Dedication is about being stirred, passionate and highly tangled in work (Rayton and Yalabik, 2014). Dedication is an individual's stemming a sense of implication from job, feeling passionate and delighted about the given work, and feeling stirred and dared by the work (Song et al., 2012).

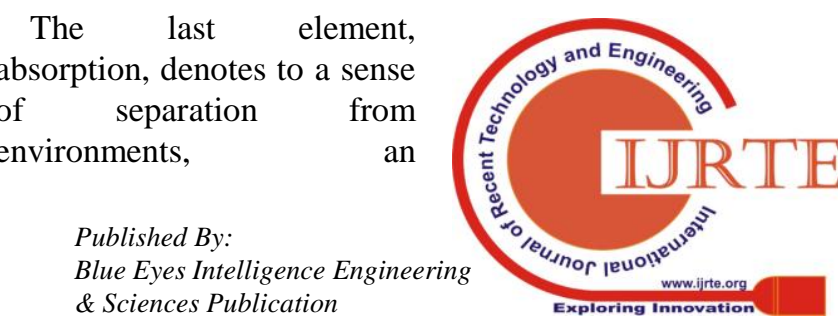


extraordinary level of captivation on work, and a common absence of conscious mindfulness of the volume of time used up on the job (Rayton and Yalabik, 2014). Absorption means attentiveness and being captivated in employees' job, whereby transitory time will be immaterial and being disconnected from the work has some worries for them. Moreover, it is enjoyable to have work practice for peoples. They do that, merely for having that and compensating high disbursement for work is not such vital issue which it is for the others (Hayati et al., 2014).

\section{RESEARCH OBJECTIVES}

The following research objectives have been formulated to support the study;

1. To test whether the Dimensions of Employee Engagement are at moderate level.

2. To test whether there is a significant relationship among Dimensions of Employee Engagement.

3. To test whether there is a significant difference between the Genders with regard to the Dimensions of Employee Engagement.

4. To test whether there is a significant difference among Educational Qualification with regard to Dimensions of Employee Engagement.

\section{RESEARCH METHODOLOGY}

The research work made use of both primary and secondary data. Information extracted from journals and other documented materials were used as secondary data. Questionnaire was used as the primary data instrument which was developed 7 point rating scales i.e $0=$ Never, $1=$ Almost never (i.e. A few times a year or less), $2=$ Rarely (i.e. Once a month or less), 3 = Sometimes (i.e. A few times a month), $4=$ Often (i.e. Once a week), 5 = Very often (i.e. A few times a week), 6 = Always (i.e. Every day) to elicit relevant information from the respondents. The respondents were chosen through the Non-Probability Convenience sampling technique in the course of administering the questionnaire. The respondents for the study have a total number of 321 employees from different Non-Banking Financial Companies located in the Districts of Chennai, Kancheepuram and Thiruvallur of Tamil Nadu, India.

The administered questionnaire has two sections labeled as section $\mathrm{A}$ and $\mathrm{B}$. The section $\mathrm{A}$ has information on the bio data of the respondents while section $\mathrm{B}$ has information inform of questions on the Employee Engagement of the respondents, which was measured along the three dimension of such as Vigor, Absorption and Dedication. The research design followed in the study is Descriptive Research Design. Descriptive statistics, Chi-Square Goodness of Fit, Correlation Co-efficient, Mann-Whitney U Test, and Krushkal Wallis Test were used to analyse the data collected and to test the hypotheses stated at 0.05 level of significance.

\section{RESEARCH HYPOTHESIS}

Evolving from the review of literature to guide the direction of the study the below hypothesis were formulated;

H1: The Dimensions of Employee Engagement are equally distributed.

$\mathrm{H} 2$ : There is no relationship among the Dimensions of
Employee Engagement.

H3: There is no significant difference between mean rank of Men and Women with regard to Dimensions of Employee Engagement.

$\mathrm{H} 4$ : There is no significant difference among mean rank of Educational Qualification with regard to Dimensions of Employee Engagement.

\section{DATA ANALYSIS AND INTERPRETATIONS}

Table I below shows 115 respondents (i.e. 35.8 percent) have High level of Employee Engagement, 118 respondents (i.e. 36.8 percent) have Low level of Vigor Dimension of Employee Engagement, 194 respondents (i.e. 60.4 percent) have Moderate level of Dedication Dimension of Employee Engagement and 163 respondents (i.e. 50.8 percent) have Moderate level of Absorption Dimension of Employee Engagement.

Table I. Descriptive Statistics for Overall and 3 Dimensions Employee Engagement

\begin{tabular}{|c|c|c|c|c|c|c|c|c|}
\hline \multirow{2}{*}{ Level } & \multicolumn{2}{|c|}{ Employee Engagement } & \multicolumn{2}{c|}{ Vigor } & \multicolumn{2}{c|}{ Dedication } & \multicolumn{2}{c|}{ Absor ption } \\
\cline { 2 - 9 } & Frequency & Percent & Fre quency & Percent & Fre quency & Percent & Frequency & Percent \\
\hline Low & 95 & 29.6 & 118 & 36.8 & 57 & 17.8 & 82 & 25.5 \\
\hline Moderate & 111 & 34.6 & 101 & 31.5 & 194 & 60.4 & 163 & 50.8 \\
High & 115 & 35.8 & 102 & 31.8 & 70 & 21.8 & 76 & 23.7 \\
\hline Total & 321 & 100.0 & 321 & 100.0 & 321 & 100.0 & 321 & 100.0 \\
\hline
\end{tabular}

Table II. Descriptive Statistics for Gender

\begin{tabular}{|c|c|c|}
\hline Gender & Frequency & Percent \\
\hline Men & 248 & 77.3 \\
\hline Women & 73 & 22.7 \\
\hline Total & $\mathbf{3 2 1}$ & $\mathbf{1 0 0}$ \\
\hline
\end{tabular}

Table II above has 248 male respondents representing $77.3 \%$ of the total respondents and 73 were female respondents representing $22.7 \%$ of the total respondents. The implication of this was that there were more of male respondents than female respondents in the study done at NBFC's.

Table III. Descriptive Statistics for Educational Qualification

\begin{tabular}{|c|c|c|}
\hline Educational Qualification & Frequency & Percent \\
\hline Under Graduate & 92 & 28.7 \\
\hline Post Graduate & 80 & 24.9 \\
\hline Professional & 95 & 29.6 \\
\hline Others & 54 & 16.8 \\
\hline Total & $\mathbf{3 2 1}$ & $\mathbf{1 0 0}$ \\
\hline
\end{tabular}

Table III above has 95 Professional respondents representing 29.6 percent of the total respondents, 92 Under Graduate respondents representing 28.7 percent, 80 Post Graduate respondents representing 24.9 percent and 54 other qualified respondents representing 16.8 percent of the total respondents.

Published By: 
Table IV. Chi-Square Test for Goodness of Fit of Dimensions of Employee Engagement

\begin{tabular}{|c|c|c|c|c|}
\hline $\begin{array}{c}\text { Level of } \\
\text { Employee } \\
\text { Engagement }\end{array}$ & Frequency & Percent & $\begin{array}{c}\text { Chi-Square } \\
\text { Value }\end{array}$ & $\begin{array}{c}\text { p } \\
\text { Value }\end{array}$ \\
\hline Low & 95 & 29.6 & & \\
\cline { 1 - 3 } Moderate & 111 & 34.6 & \multirow{2}{*}{2.093} & 0.351 \\
\hline High & 115 & 35.8 & & \\
\hline Total & $\mathbf{3 2 1}$ & $\mathbf{1 0 0 . 0}$ & & \\
\hline
\end{tabular}

Since $\mathrm{p}$ Value is 0.351 , from Table IV above, the $\mathrm{H} 1$ is accepted at 5 Percent level of significance. Hence we conclude that the levels of Employee Engagement are equally distributed. Based on percent the most of respondents belong to High level of Employee Engagement.

Table V. Pearson Correlation Coefficient among Dimensions of Employee Engagement

\begin{tabular}{|c|c|c|c|}
\hline $\begin{array}{c}\text { Dimensions of } \\
\text { Employee } \\
\text { Engagement }\end{array}$ & Vigor & Dedication & Absorption \\
\hline Vigor & 1.000 & $0.429 * *$ & $0.580^{* *}$ \\
\hline Dedication & & 1.000 & $0.848^{* *}$ \\
\hline Absorption & & & 1.000 \\
\hline
\end{tabular}

Note: ** Significant at the 0.01 level.

From Table V above, the Correlation among all Dimensions of Employee Engagement are significant at 1 percent level so we reject the $\mathrm{H} 2$, hence there is correlation among the Dimensions of Employee Engagement.

The Correlation Coefficient between Dedication and Absorption Dimension of Employee Engagement is 0.848 which indicate 71.9 percent positive relationship between Dedication and Absorption and is significant at 1 percent level; the Correlation Coefficient between Vigor and Absorption Dimension of Employee Engagement is 0.580 which indicate 33.6 percent positive relationship between Vigor and Absorption and is significant at 1 percent level and the Correlation Coefficient between Dedication and Vigor Dimension of Employee Engagement is 0.429 which indicate 18.4 percent positive relationship between Dedication and Vigor and is significant at 1 percent level.

Table VI. Mann-Whitney U Test for significant difference between Mean Rank of Men and Women with regard to Dimensions of Employee Engagement

\begin{tabular}{|c|c|c|c|c|}
\hline $\begin{array}{c}\text { Dimensions of } \\
\text { Employee } \\
\text { Engagement }\end{array}$ & \multicolumn{2}{|c|}{ Gender } & $\begin{array}{c}\text { Z } \\
\text { Value }\end{array}$ & \multirow{2}{*}{ p Value } \\
\cline { 1 - 3 } Vigor & $\begin{array}{c}153.5 \\
4\end{array}$ & 186.35 & 2.681 & $0.007 * *$ \\
\hline Dedication & $\begin{array}{c}185.3 \\
7\end{array}$ & 78.22 & 9.072 & $<0.001^{* *}$ \\
\hline Absorption & $\begin{array}{c}176.5 \\
3\end{array}$ & 108.24 & 5.659 & $<0.001 * *$ \\
\hline $\begin{array}{c}\text { Overall } \\
\text { Employee } \\
\text { Engagement }\end{array}$ & $\begin{array}{c}174.4 \\
7\end{array}$ & 115.25 & 4.836 & $<0.001 * *$ \\
\hline
\end{tabular}

Note: ** Significant at the 0.01 level.
From Table VI above, since $\mathrm{p}$ value is less than 0.001 the $\mathrm{H} 3$ is rejected at 1 percent level with regard to Dimension of Employee Engagement. Hence there is a significant difference between Men and Women with regard to Dimension of Employee Engagement. Based on Mean Rank Men have better opinion on Dedication, Absorption and Overall Employee Engagement than Women. Based on Mean Rank Women has better opinion on Vigor than Men.

Table VII. Kruskal Wallis Test for significant difference among Mean Rank of Educational Qualification with regard to Dimensions of Employee Engagement

\begin{tabular}{|c|c|c|c|c|c|c|}
\hline \multirow[b]{2}{*}{$\begin{array}{l}\text { Dimensions of Empl oyee } \\
\text { Engagement }\end{array}$} & \multicolumn{4}{|c|}{ Educational Qualification } & \multirow[b]{2}{*}{$\begin{array}{l}\text { Chi-Square } \\
\text { Value }\end{array}$} & \multirow[b]{2}{*}{ p Value } \\
\hline & $\begin{array}{l}\text { Under } \\
\text { Graduate }\end{array}$ & $\begin{array}{c}\text { Post } \\
\text { Graduate }\end{array}$ & Professional & Others & & \\
\hline Vig $\alpha$ & 211.80 & 172.58 & 101.31 & 162.31 & 69.449 & $<0.001^{44}$ \\
\hline Dedication & 98.04 & 201.02 & 205.65 & 130.43 & 93.130 & $<0.001^{* 4}$ \\
\hline Absorption & 151.46 & 109.07 & 234.72 & 124.51 & 98.891 & $<0.001^{* 4}$ \\
\hline $\begin{array}{l}\text { Overall Employes } \\
\text { Engagement }\end{array}$ & 163.28 & 178.85 & 148.14 & 153.30 & 5.307 & 0.151 \\
\hline
\end{tabular}

Note: ** Significant at the 0.01 level.

From Table VII above, since p value is less than 0.001 the $\mathrm{H} 4$ is rejected at 1 percent level with regard to Vigor, Dedication and Absorption Dimensions of Employee Engagement, hence there is a significant difference among Educational Qualification with regard to Vigor, Dedication and Absorption Dimensions of Employee Engagement.

There is no significant difference among Educational Qualification with regard to Overall Employee Engagement, since $\mathrm{p}$ value is greater than 0.05 , hence $\mathrm{H} 4$ is accepted at 5 percent level with regard to Overall Employee Engagement.

\section{DISCUSSION OF FINDINGS}

The findings of the study based on Statistical tools revealed that there are more respondents with High level of Employee Engagement and when it comes to the Dimensions of Employee Engagement, more respondents have Low level of Vigor, Since Vigor is one of the aspects of Employee Engagement that implies high levels of energy and mental resilience while working; and Moderate level of Dedication and Absorption. Dedication is an individual's deriving a sense of significance from work, feeling enthusiastic and proud about the given job, and feeling inspired and challenged by the job (Song et al., 2012). Absorption in the job requires concentration and being engrossed in people's work, whereby passing time will be intangible and being detached from the job has some difficulties for the respondents. When taking into consideration all the three dimensions of Employee Engagement, the overall the level of Employee Engagement in NBFC's is high.

The Chi-Square Test for Goodness of Fit indicated that the Overall Employee Engagement of respondents is equally distributed, revealing that there were almost equal number of respondents in Low, Moderate and High level of Employee Engagement.

The Pearson Correlation Coefficient explains that there is positive relationship among all the 3 Dimensions of 
Employee Engagement i.e. among Vigor, Dedication and Absorption; and there is 71.9 percent positive relationship between Dedication and Absorption, since these 2 Dimensions of Employee Engagement are theoretically related to each other as well i.e. when respondents are enthusiastic in their work the concentration towards the job will be high and they will focused in their job.

The Mann Whitney U test revealed that there is a difference between Men and Women with regard to opinion on Dimension of Employee Engagement. Based on the Mean Rank Men have better opinion on Dedication, Absorption and Overall Employee Engagement than Women, as normally Men will have more enthusiasm and concentration towards the job than women respondents. Based on Mean Rank Women has better opinion on Vigor than Men, since women have high levels of energy and mental resilience in whatever work they get involved in.

The Krushkal Wallis Test further revealed that there is a difference among respondents with different Educational Qualification with regard to Vigor, Dedication and Absorption Dimensions of Employee Engagement, also that the respondents with different Educational Qualifications have same level of Overall Employee Engagement. Based on the Mean Rank Under Graduates have better opinion on Vigor Dimension of Employee Engagement and Professional have better opinion about Dedication and Absorption Dimensions of Employee Engagement.

\section{CONCLUSION}

Given that employee engagement is an idea that helps develop strong positive attitudes among people towards their work and their organisation, and this plays a major role in ensuring that they give their best even when times are tough, surely we need to improve it now more than ever. So because of the importance of employee engagement in organizations, in this research we assessed the employees' engagement and its dimensions in NBFC's located in the 3 Districts of Tamilnadu, India. The results revealed that employee engagement is higher and its 2 dimensions (i.e. Dedication and Absorption are at the moderate level and Vigor is at lower level among employees of NBFC's. Some recent research has shown that people who have positive attitudes towards their organisations do not necessarily work harder. On the other hand, people who focus on solving problems and behave positively are not necessarily loyal to their organisation. (Shekari, 2015).

In present study, the results of opinion about the dimensions of employee engagement indicated that the level of Vigor dimension of employee engagement is lower than other dimensions in NBFC's located in the 3 Districts of Tamilnadu, India. That is, Vigor dimension needs more attention. So to promote this dimension managers must provide a climate in their organization so that employees:

- Find the way to increase their energy

- Be mentally flexible in the job

- Be persistent in their effort even during setbacks

- Be determined to invest in their job

\section{REFERENCES}

1. Berkel, J.V, Proper, K.I., Boot, C.R., Bongers, P.M. and vanderBeek, A.J. Mindful "Vitality in Practice": an intervention to improve the work engagement and energy balance among workers; the development and design of the randomized controlled trial. BMC $\begin{array}{llll}\text { Public } & \text { Health, } & 11(1): & 736 .\end{array}$ http://doi.org/10.1186/1471-2458-11-736.

2. Breevaart, K., Bakker, A.B. and Demerouti, E. Daily self-management and employee work engagement. Journal of Vocational Behavior, 84(1): 31-38. 2014. http://doi.org/10.1016/j.jvb.2013.11.002.

3. Breevaart, K., Bakker, A.B., Hetland, J., Demerouti, E., O.K., Olsen and Espevik, R. Daily transactional and transformational leadership and daily employee engagement. Journal of Occupational and $\begin{array}{ll}\text { Organizational } & \text { Psychology. }\end{array}$ http://dx.doi.org/10.1111/joop.12041.

4. Cooper-Thomas, H.D., Paterson, N.L., Stadler, M.J. and Saks, A.M The relative importance of proactive behaviors and outcomes for predicting newcomer learning, well-being, and work engagement. Journal of Vocational Behavior, 84(3): 318-331. 2014 http://doi.org/10.1016/j.jvb.2014.02.007.

5. Hayati, D., Charkhabi, M. and Naami, A. The relationship between transformational leadership and work engagement in governmental hospitals nurses: a survey study. SpringerPlus 3(25). 2014 http://doi.org/10.1186/2193-1801-3-25

6. Inoue, A., Kawakami, N., Tsuno, K., Shimazu, A., Tomioka, K., \& Nakanishi, M. Job demands, job resources, and work engagement of Japanese employees: A prospective cohort study. International Archives of Occupational and Environmental Health, 86(4): 441-449. 2013. http://doi.org/10.1007/s00420-012-0777-1

7. Kahn, W. A. Psychological conditions of personal engagement and disengagement at work. Academy of Management Journal, 33(4): 692-724. doi: 10.2307/256287, 1990.

8. Kanste, Outi Work engagement, work commitment and their association with well-being in health care. Scand J Caring Sci, 25: 754-761. 2011.

9. Latham GP, Pinder CC, Work motivation theory and research at the dawn of the twenty-first century. Annu Rev Psychol 56:485-516, 2005.

10. Rayton, B. a, \& Yalabik, Z. Y. The International Journal of Human Work engagement, psychological contract breach and job satisfaction. The International Journal of Human Resource Management. Taylor \& Francis. 2014. http://doi.org/10.1080/09585192.2013.876440

11. Rich, B.L., Lepine, J.A., and Crawford, E.R., 'Job Engagement: Antecedents and Effects on Job Performance,' Academy of Management Journal, 53: 617-635. 2010.

12. Schaufeli, W. B., Bakker, A. B., \& Salanova, M. The measurement of work engagement with a brief questionnaire: A cross-national study. Educational and Psychological Measurement, 66: 701-716. 2006.

13. Schaufeli, WB and Bakker, AB. Defining and measuring work engagement: bringing clarity to the concept. In: Bakker AB, Leiter MP (eds) Work engagement: a handbook of essential theory and research Psychology Press, New York, 10-24. 2010.

14. Shekari H. Evaluating the Three Dimensions of Work Engagement in Social Security Organization of Yazd Province in Iran. J. 2015.

15. Song, J. H., Kolb, J. A., Lee, U. H., \& Kim, H. K. Role of Transformational Leadership in Effective Organizational Knowledge Creation Practices: Mediating Effects of Employees' Work Engagement. HUMAN RESOURCE DEVELOPMENT QUARTERLY, 23(1):, 65-101. 2012. http://doi.org/10.1002/hrdq

16. Towers Perrin, Closing the engagement gap: A road map for driving superior business performance. Retrieved from http://www.towerswatson.com 2007.

17. Towers Perrin, Working today: Understanding what drive employee engagement. Retrieved from http://www.towerswatson.com 2003.

18. Wagner, R., \& Harter, J. K. 12: The elements of great managing. New York, NY: Gallup Press. 2006. 